\title{
Swans in Sugarcane Fields: Proletarian Ballet Dancers and the Cuban Revolution's Industrious New Man
}

Lester Tomé

Smith College, ltome@smith.edu

Follow this and additional works at: https://scholarworks.smith.edu/dan_facpubs

Part of the Dance Commons

\section{Recommended Citation}

Tomé, Lester, "Swans in Sugarcane Fields: Proletarian Ballet Dancers and the Cuban Revolution's Industrious New Man" (2017). Dance: Faculty Publications, Smith College, Northampton, MA.

https://scholarworks.smith.edu/dan_facpubs/1 


\section{Swans in Sugarcane Fields: Proletarian Ballet Dancers and the Cuban Revolution's Industrious New Man \\ Lester Tomé \\ Dance Research Journal 49/2 (2017), 4-25 \\ https://doi.org/10.1017/S0149767717000171}

Note: This is a post-print version of the article, before a few minor revisions and copyediting. You can download the final, published version of the article from the website of Dance Research Journal, or through any of the full-text databases that carry the journal (Project Muse, Cambridge University Press, EBSCO, International Index to Performing Arts). Please access the published version to quote from the article.

Abstract: In the 1960s, the initial decade of the Cuban Revolution, policies of proletarianization of culture intersected an economic model built upon the heroic labor of the New Man - the ideal revolutionary and communist worker. Adapting the practice of ballet to this Marxist context, ballet dancers took their art to the working classes through popular performances and outreach events in farms and factories. Given the centrality of manual work to the Revolution's ideology, dancers drew upon their own physical labor both in ballet and agriculture to establish an even stronger association with the working classes and embody the New Man's morality. Known for their strict work ethic, Alicia Alonso and other baller dancers became public examples of hard work for the nation - one way of fulfilling the politico-pedagogical role that the state expected from artists. At the same time, media representations of female dancers' labor enabled formulations of the New Man's gendered counterpart: the New Woman.

Keywords: ballet, Cuba, Cuban Revolution, labor, New Man, New Woman, proletarianization, communism, cultural policy.

Bio: Lester Tomé, PhD (ltome@smith.edu), is a faculty member in the Smith College Dance Department and the Five College Dance Department. He has been a Visiting Scholar at Harvard University (2013-14) and a fellow of the National Endowment for the Humanities (2014-15). His articles have appeared in journals, magazines and edited volumes in the US, UK, Spain, South Korea and Cuba. He coordinates the Working Group for Latin American, Latino and Caribbean Dance Studies of the Society of Dance History Scholars. 


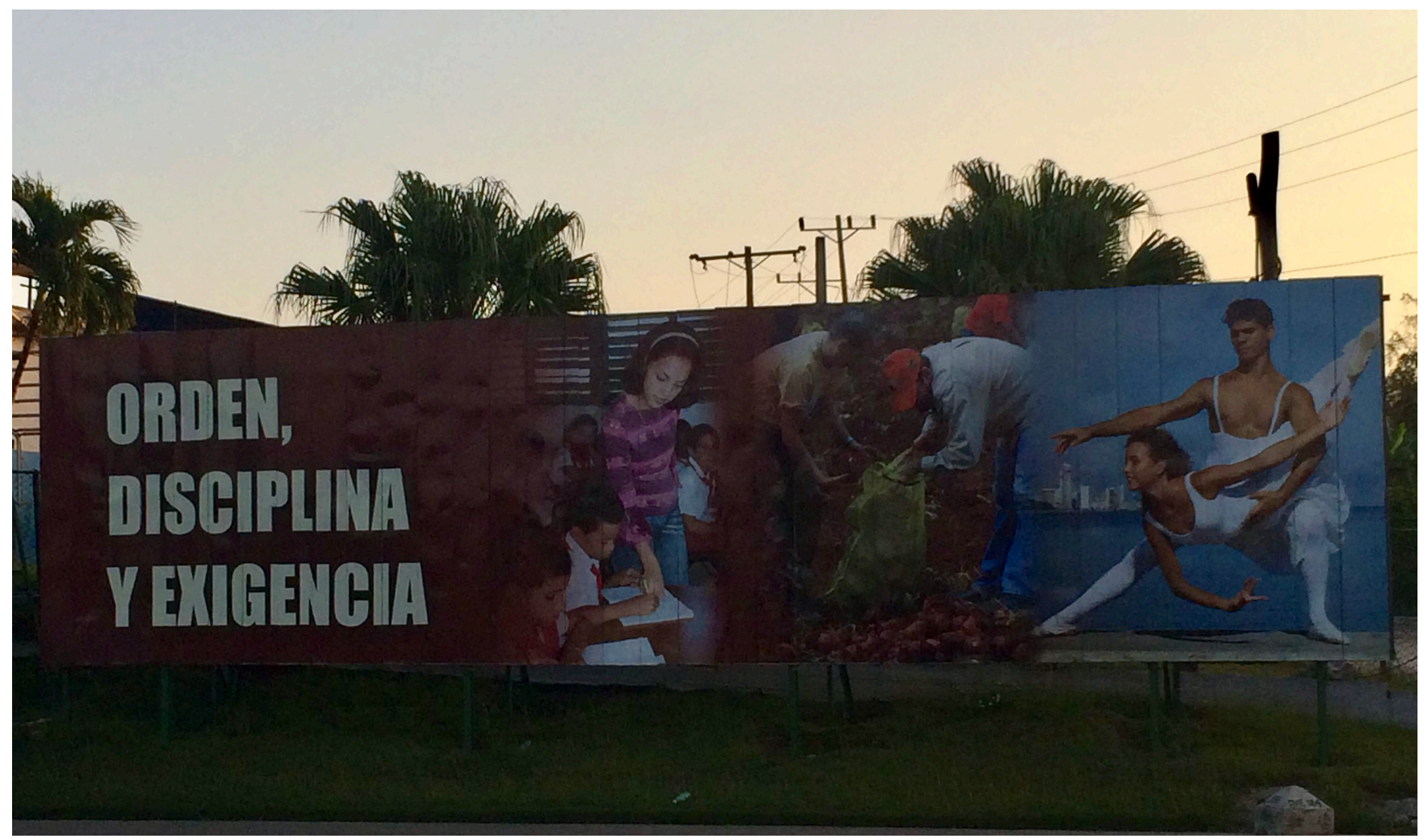

In 2015, visitors to Havana drove by a billboard at the exit of the José Martí International Airport, on Rancho Boyeros Avenue, that juxtaposed photographs of a teacher at work in her classroom, a group of farmers picking potatoes and two ballet dancers holding a stylized pose (Photo 1). A slogan on the billboard called for "organization, discipline and exigency". To foreign visitors, the assemblage of images and text must have been puzzling. What could the connection between teachers, farmers and dancers be, and what could the words mean? Locals, however, could instantly recognize a call to the country's workforce to fulfill its labor duties with consciousness and efficiency - a message to which Cubans have been exposed for more than five decades. Showcasing ballet dancers to underscore this call was consistent with a political discourse that, since the 1960s, has invoked ballet's values of discipline, dedication and selfdemand to symbolize a communist work ethic. Following the advent of the Cuban Revolution in 1959, dancers sought to reposition their work and social identity along the lines of proletarian ideology. The integration of dancers in the billboard, next to farmers and teachers, encoded the idea of national unity: the tenet that all Cubans, regardless of profession, militated in the ranks of the proletariat. The billboard also referenced the 1960s rhetoric of the "New Man": the chimeric protagonist of the Revolution's grand narrative, the almost superhuman subject whose political consciousness, hard work, personal sacrifice and collectivist spirit produced radical social change. Education (symbolized by the teacher), labor (represented by the farmers) and the arts (illustrated by the dancers) were constitutive realms of the New Man. The classic definition of the New Man in Ernesto "Che" Guevara's essay Socialism and Man in Cuba foregrounded the 
role of education in transforming the common man into the archetypical revolutionary. It also explained the New Man's devotion to labor as a social duty: the ideal revolutionary engaged heroically in the work-intensive tasks of building a new society. At the same time, Guevara proclaimed the political function of the arts, which should "sing the praise of the New Man with the authentic voice of the people" (Guevara 1966, 20). ${ }^{1}$

In this article, I foreground ballet as an arena for articulations of the New Man throughout the 1960s and until the historic Ten-Million-Ton Sugar Harvest of 1970, while considering interrelationships between art, ideology, education and labor at the time. ${ }^{2}$ The fundamental changes that the Revolution brought to artistic production during this period corresponded with a process that Ana Serra terms proletarianization of culture, which sought to realize principles of accessibility to the arts, establish a political function for artistic production and redefine the status of artists in society. State support of the arts presupposed that artists fulfilled the cultural needs of the working classes and undertook a role in the political education of the masses. It also assumed that artists relinquished their status as an intellectual elite and embraced, instead, a proletarian identity (Serra 2007, 3-5, 13, 59-66). This article examines the efforts of the Ballet Nacional de Cuba (BNC) to popularize the dance form through extensive performances across the island and outreach events in farms, factories and other workplaces. In considering how ballet dancers realized the program of proletarianization of the arts, I stress the centrality of physical labor to the Revolution's ideology and New Man discourse. Dancers drew on their own labor - both work specific to ballet and work in agriculture - to establish affiliation with the proletariat and embody the ideal of the hard-working revolutionary. Rather than addressing the potential of ballet to celebrate workers and the New Man through choreographic production, I analyze how members of the BNC and the Ballet de Camagüey fulfilled the politico-pedagogical function expected from artists by serving as eloquent examples of arduous work for the rest of the nation. Discussed here too is how ballet dancers' embodiments of disciplined labor amounted to performative actions in what Lillian Guerra characterizes as the political theater of the Revolution: the construction of a hyper-real, mythical narrative of the transformation of the individual and society (Guerra 2012, 30). Moreover, I probe how media representations of the work of female dancers, including Alicia Alonso, the BNC's prima ballerina, enabled formulations of the New Man's gendered counterpart: the New Woman. ${ }^{3}$ And, given the relationship between physical labor and Afro-Cuban workforce, I suggest as well that the proletarianization of ballet entailed a symbolic repositioning of the dance form not only in terms of class, but also race.

This argument rests on examination of the Revolution's cultural policy and political economy, articulated by ideologues such as Fidel Castro and Ernesto Guevara. Scrutiny of the weekly magazine Bohemia from 1959 to 1970, as well as of other primary sources, was essential in reconstructing the unconventional activities of dancers during the period and tracing the symbolic appropriation of their labor by propagandistic narratives of the New Man and the New 
Woman. ${ }^{4}$ Interviews of various members of the BNC who participated in the artistic, political and economic crusades of the era yielded an oral history supplementary of institutional and statesanctioned archival records. Those testimonials contributed both textured memories of events and balancing accounts of the fallible nature of the government's superhuman demands on workers. My analysis underscores performative means of ideological signification as operated in dancers' bodies and through those bodies' depiction in texts and photographs.

In discussions of the New Man and the proletarianization of culture, ballet constitutes a provocative object of inquiry: a high-art tradition commonly characterized as elitist and escapist, seemingly antipodal to Marxist principles. Cuba hardly stands alone as a location where ballet claimed its place within communist ideology. In her study of the Soviet ballet, Christina Ezrahi brings attention to the contested position of the dance form within a Marxist social order. Following the October Revolution in 1917, Soviet authorities debated the suitability of maintaining the practice of ballet. Many officials found it culturally obsolete - a reactionary vestige of the monarchic regime. It became imperative for the genre to acquire new relevance in the sociopolitical scenario of a proletarian establishment. This required abandoning a model of elitist spectatorship and conforming to Marxist predicates of the social function of arts. Accordingly, ballet was repurposed as an instrument in the Soviet project to raise the cultural level of the working classes (Ezrahi 2012, 1-29). Moreover, authorities sought to enlist Soviet choreographers in the production of propaganda works that promoted the formation of communist subjects.

The phenomenon analyzed by Ezrahi had its equivalent in the Cuban context, in which ballet dancers, as indicated above, grappled with similar questions about the social purpose of the arts in a Marxist setting. But there were significant differences. In Cuba, expressions of high art were associated with bourgeois culture only in a general sense-unlike in the Soviet Union, where ballet was a very clear symbol of the prerevolutionary establishment and, consequently, became a focal point of debates pitting czarist artistic traditions against proletarian ideology. Never in the early years of the Cuban Revolution did the debates about the social role of the arts single out ballet for its political genealogy. Cuba also differed from the Soviet Union in questions of aesthetic orthodoxy. By the time the Cuban Revolution took power, socialist realism had already shown its limitations in other communist countries. Guevara himself noted the unviability of such an artistic dogma, while Fidel Castro assured artists of their freedom to engage in stylistic experimentation (Castro 1961, 45; Guevara 1966, 18-19). ${ }^{5}$ Given their openness in matters of style, Cuban cultural authorities did not raise political arguments about ballet aesthetics, unlike in the Soviet Union, where, as Janice Ross indicates, the official expectation that choreographers conformed to pre-established stylistic parameters weighed heavily on ballet and curtailed its autonomy (Ross 2015). Unencumbered with such polarizing issues of aesthetic freedom, the proletarianization of ballet in Cuba prioritized other issues: making the art accessible to the working classes and articulating an image of the dancers as 
workers themselves.

Which raises important points about the relationship of dance to labor. Regarding dancers as workers meant recognizing the labor of ballet and, more specifically, equating the profession's hard physical demands with the arduous activities through which manual workers fueled production and sustained the Revolution. Additionally, embodying the ideal of the New Man meant, for dancers, engaging in affective performances of labor in consonance with a political discourse of heroism. In his study of the US dance culture during the Great Depression, Mark Franko (2002) elucidates the intersections of dance performance, labor concepts and class identity. The Great Depression constituted, similarly to the initial decade of the Cuban Revolution, a period of economic hardship in which dancers could not operate at the margins of widespread debates about labor, production and politics. In both situations, the status of dance as work and of dancers as workers generated social interest. The scrutiny of dance as a metaphor of a production system is of particular relevance to my argument. Franko's most telling example of it concerns chorus dancing, as performed in the Ziegfeld Follies and later adapted for Busby Berkeley's films. Chorus dancing embodied labor efficiency in industrial capitalism. With their homogeneous appearance, orderly row formation, precise leg kicks and synchronized choreography, the chorus girls rendered an idealized image of machine-like, Taylorized factory workers $(3,6,30-32){ }^{6}$ Analogously, in the Cuban context ballet mirrored the grueling physical effort that the Revolution exacted from agricultural and industrial workers. Rather than concentrating on ballet performances, in which dancers attempt to convey effortlessness, here I pay attention to instances in which close observation of dancers and media coverage of their work unveiled utmost physical rigor.

If ballet came to symbolize hard work during the initial decade of the Revolution, it was because it modeled notions of discipline and sacrifice central to the official definition of labor. As Franko contends, the correlation of dance to labor entails not a mere physical identification of dance training, choreography or performance with work, but also a bodily articulation of political affects. Franko builds upon Raymond Williams's concept of structure of feeling, which points, in Williams's own words, to "meanings and values as they are actively lived and felt" by a specific social group or class in a particular environment and period (Williams 1977, 132). Franko argues that this process manifests corporeally, in identifiable gestures and physical expressions: the bodily actions of cheerful chorus girls established an intelligible index of the positive mindset and emotional equilibrium expected from Taylorized workers (Franko 2002, 31, 40-41). I interrogate the Cuban ballet dancers' corporealization of a structure of feeling both inside and outside dance. Whether they worked in the dance studio rehearsing feverishly for an upcoming performance or in a sugarcane field striving to meet an agricultural quota vital to the nation's economy, these dancers typified the heroic emotions exalted by the Revolution's communist mode of production and New Man ideology. 


\section{Ballet for the Masses: From the Opera House to Stadiums and Factories}

Alicia and Fernando Alonso founded the Ballet Alicia Alonso in 1948. The troupe functioned with the partial aid of state subventions until 1956, when the administration of Fulgencio Batista withdrew the government's financial assistance and, in protest, the Alonsos put the ensemble's operations in a hiatus. In 1959, the Alonsos reorganized the ensemble now known as the Ballet Nacional de Cuba (BNC) thanks to generous support extended by the government of Fidel Castro. Funding the arts counted among the new government's signature social policies. The BNC was one of several cultural institutions established that same year, including the Modern Dance Ensemble, the Cuban Institute of the Cinematographic Art and Industry and the National Press. ${ }^{7}$ As Rebecca Gordon-Nesbitt explains, Marxist and humanist perspectives informed the Revolution's regard for cultural production as essential to the transformation of society. The arts were prized as an instrument for cultivating the social consciousness indispensable to build a new political order. The state also held the arts in great value for their perceived role in countering the alienation of the working classes in capitalism. In the new Cuba, the arts would nurture the workers' spirituality. If under previous governments the arts had been a privilege of the bourgeoisie, now artistic production and consumption were to be democratized (GordonNesbitt 2015, 99-119). Addressing a group of writers and artists in 1961, Castro articulated the foundation of this cultural policy: "Developing the arts and culture is one of the Revolution's fundamental goals, precisely so that the arts and culture finally become a true patrimony of the people. In the same way that we want a better existence for the people in the material sphere, we want a better existence for the people in the spiritual sphere" (Castro 1961, 47). With artistic production institutionalized within a framework of state financing, this cultural policy dominated the mission of arts organizations. Law 812 from 1960, which made state funding of the BNC permanent, instructed the troupe to realize the government's directive: "Culture should not be the patrimony of a few, but, on the contrary [...] reach all of the Nation's social classes, particularly workers and other popular sectors" (Law 812, 1960).

Dancers embraced this mandate enthusiastically. Already before the Revolution, in 1951, the Alonsos' troupe had pledged to "take ballet out of a frame of exclusivity" and "bring it to the people through any possible channels" (Ballet Alicia Alonso 1951). Two years later, in addressing the Continental Congress of Culture in Santiago, Chile, Fernando Alonso reiterated the vision of ballet as "an art of the people and for the people" (F. Alonso 1953, 144). ${ }^{8}$ After 1959, this philosophy found fertile ground in the Revolution' cultural policies, as the BNC sought to build an alliance with the working classes. On February 3, within one month of the Revolution's victory, the Alonsos' regrouped ensemble dedicated their reappearance to the Rebel Army — which was, overwhelmingly, an army of peasants (Ballet de Cuba 1959b). Later that year, on September 17, the program notes for a performance of Giselle called for Cubans of all social classes and professions to reconstruct the country together in the wake of Batista's dictatorship: 
Each Cuban to his place of combat: the farmer to the plow, the worker to the workshop, the professional to his own activity; on our part, we [dancers] pledge to work toward our organization and professional growth with more dedication than ever, to take the best of our art to our people [and] carry a message of love and beauty to the "poor of the land"" (Ballet de Cuba 1959a). ${ }^{9}$

The statement made it clear that ballet dancers would not merely perform for the people, but also work with the people, as one and the same with farmers and workers, in the Revolution's project of national reconstruction.

Taken as an example of the BNC's outreach efforts, the ensemble's activities throughout 1962 illustrated a strategy for promoting accessibility through frequent performances, low ticket prices, widespread touring and appearances in popular venues. The magazine Bohemia documented this strategy in articles about ballet published during the year. In May, after presentations of Swan Lake in Havana, Bohemia pronounced that only in a socialist country like Cuba workers could attend the ballet for 50 cents (Quiroga 1962a). Tickets for performances were kept at a subsidized price that made them extremely affordable, even for the working classes. In June, the magazine observed that Alicia Alonso, finding theaters too small a venue, had performed in Havana's Latin American Stadium for an estimated audience of 50,000 spectators. A note announced that, next, the ballerina planned to take the BNC to remote rural locations and perform for audiences of farmers (Núñez 1962; Quiroga 1962b). Other popular performances took place within a few weeks. On July 26, the company presented Giselle to the large audience that filled a sports venue in Santiago on occasion of a political holiday marking the beginning of the guerilla insurgency against Batista's regime. The performance was televised nationwide, multiplying the number of its spectators. Before the end of the month, Alonso and the BNC danced Giselle for a crowd of workers vacationing in the Guamá Tourist Center, in the southern marshlands of Matanzas province (Medialdea 1962; Quiroga 1962c). By early October, Alonso was performing La fille mal gardée in front of 4,000 delegates to the First Congress of the Cuban Women's Federation (Mujer cubana 1962).${ }^{10}$ Crowning that year's outreach efforts, a few days later the ensemble undertook a national tour with the explicit goal of promoting ballet to the masses. The six-week tour began on October 7 and overlapped with the Missile Crisis. In spite of the nation's state of emergency, the ensemble followed through with the plan to complete over twenty performances in thirteen cities across the whole island, including presentations in stadiums and other outdoors venues in San Antonio de los Baños, Jovellanos, Bayamo, Manzanillo, Holguín and Las Tunas. These activities effectively imprinted an image of ballet dancers as artists of the people. By the end of the decade, Bohemia characterized Alonso as a ballerina who cherished dancing "for the bleachers and fields of the stadiums, the open-air theatres [and] the public squares" (Díaz Castro 1970, 5). 
Going further, the BNC developed a program of visits to factories, farms, schools and military bases with the purpose of expanding its audience. According to Miguel Cabrera, the ensemble's resident historian and coordinator of the outreach program, on such visits a group of artists performed ballet excerpts, while one of the leading dancers, sometimes Alicia Alonso, commented on the pieces on view, the history of ballet and the dancers' training regime (Cabrera 2014). The Communist Party's newspaper chronicled an instance of this type of outreach having taken place in February 1966, when Alonso and the BNC performed in the candy factory La Estrella, in Havana, as part of an arts appreciation program cosponsored by the National Council of Culture and the Cuban Workers Confederation (Experiment 1966). ${ }^{11}$ Cabrera indicates that, by the time he began working for the BNC in 1970, the troupe's outreach program had been functioning for a decade. During its tours across the island, the company made a point of appearing not only in theaters and popular venues, but also in schools and factories. The records that Cabrera began compiling in 1970 reveal the ambitious scope of the outreach program. Over the next five years, the BNC offered 121 didactic performances. The list of events from 1971 illustrates the regular presence of the troupe in workplaces. Among the locations visited that year were the Partagás Cigar Factory (July 15), the Luyanó Railroad Yards (October 13), the Havana Bus Terminal (October 14), the Alfa-Romeo Rental Car Agency (October 20), the Skoda Automobile Assembly Plant (October 26) and the presses of the newspaper Granma (December 27). ${ }^{12}$

The BNC's appearances in workplaces functioned as more than an arts accessibility initiative. In bringing intellectuals and workers together, these events were akin to the Revolution's literacy campaign of 1960-61, during which over 100,000 volunteer teachers traveled to the countryside and, for months, lodged with peasants while teaching them how to read and write. As Serra argues, the literacy campaign aimed to educate not only the illiterate peasants but also the army of teachers, made of young people from the urban middle class. Fidel Castro explicitly told the teachers that they would learn why a revolution had been necessary. They would experience first hand the economic conditions to which farmers, and by extension the working classes, had been relegated under previous governments. They would learn, too, the values of rural culture, thought to be free of the materialism associated with capitalism. Through this social experiment, the government expected the teachers to fuse their identity with the working classes (Serra 2007, 28-29, 31, 40). The same notion informed the Revolution's early cultural policies. In 1961, the First National Congress of Writers and Artists proposed a program of action that listed, among other points, the objective of "bringing the people close to the intellectual and the intellectual close to the people" (Manifiesto 1961). Similarly, in guidelines for artistic production issued in 1962, the National Council of Culture pressed for initiatives to promote "a greater degree of intimate contact between creators and the people, through coexistence in farms and factories" (Gordon-Nesbitt 2015, 184). ${ }^{13}$ 
A key component of the process of proletarianizaton of ballet, the BNC's visits to factories enabled this idealized fusion of identities between artists and workers. In itself, the journey from the opera house to the factory enacted a transformation of the dancers' social identity in accordance with the official vision of artists renouncing the ivory tower. Beyond the symbolism of that journey, the spatial configuration and format of the didactic performances propitiated meaningful identification between dancers and workers. Opposite to a traditional theater, which separates performers from viewers through architectural and theatrical conventions, the makeshift stages in factories brought dancers and workers within close proximity. The artists performed on a platform or clearing, sometimes with the audience surrounding them in arena style. These spatial arrangements reduced both the physical and psychological distance between dancers and workers (Photo 2). By including commentary, the events dispensed with the fourth wall convention and, thus, fostered a fluid connection between spectators and performers. Theatrical illusion, which masks the performer's real identity, was partial at the very least, for the dancers alternated between enacting theatrical roles and speaking as their real selves when explaining the elements of ballet. Seeing otherwise voiceless ballet dancers speak in first person rendered them relatable flesh-and-blood figures to the viewers. Bidirectional communication further narrowed the gap between performers and spectators. If the artists spoke to the workers, the workers responded to the artists with exclamations and comments. Dancer Caridad Martínez, who joined the BNC in the mid-1960s, remembered the uninhibited reactions of the workers to feats such as the ballerinas' standing on point or the men's lifting the women up high. They gasped, clapped and shouted: "That's amazing!" "How do you do that?" "Doesn't it hurt?" (Martínez 2013). The choice of choreography also contributed to closing the divide between dancers and workers. Cabrera explains that, in addition to selections from classics like Swan Lake, the events often featured excerpts of Cuban ballets (Cabrera 2014). Such works engaged the spectators through the shared cultural codes of the nation's popular music, social dances and folkloric legends. Collectively, these strategies demystified ballet dancers in the eyes of workers. ${ }^{14}$

[Article continues in the next page] 


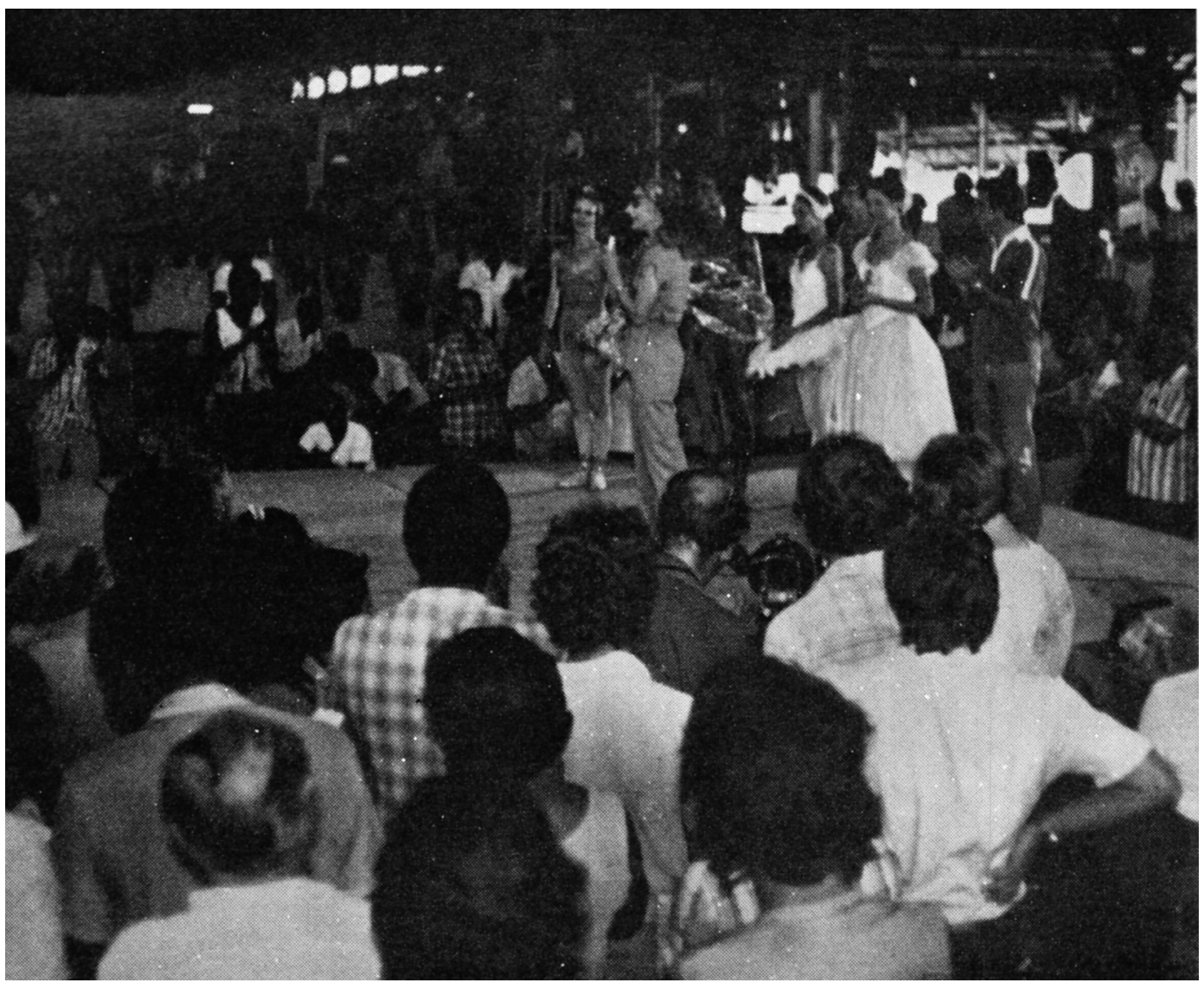

Following Franko's conceptualization of the dancing body as a signifier of politicized definitions of labor, one could argue that the BNC's performances in factories facilitated the dancers' embodiment of a working class identity. Immersed in the proletarian logic of the Revolution, artists imbued dance with labor status and, to this effect, showcased the hard work required in ballet training and performance. The talks, as indicated earlier, addressed the dancers' training system, insisting on its high physical demands and guiding values of discipline, dedication and self-exigency. Cabrera indicated that, in fact, these events often began with a demonstration of barre exercises to illustrate the dancers' daily preparation (Cabrera 2014). Representing their art in this light, dancers promoted an understanding of ballet as an activity that, like manual work, required intense physical effort and the strong will necessary to overcome pain and fatigue. To the workers, up-close observation of the artists revealed palpable evidence of strenuous labor - effort that, in a conventional theatrical venue, is masked by lights, makeup and costumes, and minimized by the distance between the audience and the stage. Looking from within proximity, viewers in farms and factories could notice the difficult details of physical coordination, the tensing of muscles and tendons, the agitated breath, the expression of exhaustion on the faces and the sweat dripping from the bodies. This glimpse into balletic practice effectively allowed the audience to see dancers as fellow workers, as individuals who executed feats of strength and endurance as demanding as those in the manual occupations of agriculture and manufacturing. Alonso sought to drive this point home during the troupe's 
nationwide tour of 1962. At a military base she asked a soldier to join her onstage and attempt lifting a light ballerina. A task seemingly simple for a strong young man turned comical when the soldier found it impossible to keep his composure while trying to lift the dancer. The ballerina's sweaty body kept slipping from his hands. Making things worse, her tutu got in the way of the maneuver. The soldier's impromptu poses were grotesque. Alonso's corollary was that ballet's facade of effortlessness hid laborious effort and skills acquired through disciplined practice (Cabrera 2014). ${ }^{15}$

It must be noted that the process of ballet's proletarianization repositioned the dance form not only in terms of social class but also race. By bridging the divide between ballet and the working classes, dancers introduced large numbers of Afro-Cuban spectators to an artistic expression that before the Revolution had been consumed by a predominantly white social elite. The performances in stadiums, squares and other mass venues broadened the audience beyond white spectators. And, given the disproportional concentration of black workers in agriculture, manufacturing, construction and the sugar industry (de la Fuente 2001, 311), the BNC's visits to farms and factories were equally instrumental in reaching constituencies more racially diverse than those for which the troupe performed in the theater. Nevertheless, the encounters between dancers and manual workers of the early 1960s brought into relief the degree of racialization that separated ballet from manual labor. In contrast to their high concentration in physical work, Afro-Cubans did not gain representation in the BNC until later in the decade. Racial integration of the troupe was delayed by an absence of classically trained Afro-Cuban dancers, a situation inherited from the pre-Revolutionary period. After Afro-Cuban students began entering statesupported ballet schools in 1961, it took several years, until later in the decade, for figures such as Caridad Martínez, Pablo Moré, Raúl Barroso and Andrés Williams to graduate and join the BNC. In the interim, mass performances and visits to workplaces allowed Afro-Cubans to experience ballet and the BNC to advance the Revolution's campaign against racism. ${ }^{16}$

\section{The New Man, Dancers' Labor and the Political Economy of Heroism}

Apart from substantiating state cultural policies, the proletarianization of ballet followed a critical fundament of the Revolution's ideology: the development of the New Man. The conceptualization of ballet as labor resonated with a definition of the New Man that underscored this ideal communist subject's commitment to work indefatigably for the nation's economic progress and social transformation. The authorities' argument for the New Man being an exemplary worker was not simply a matter of mobilizing his productivity in function of building the communist utopia. It was the immediate survival of the Revolution that was at stake. Facing a faltering economy, government leaders called upon Cubans to work harder and harder. In this context, not only did dancers highlight the intrinsic labor of ballet; they also joined efforts with millions of other Cubans in the performance of urgent agricultural tasks. 
After 1959, a succession of events and government measures led to radical transformation of the economy. Agrarian reform and nationalization of properties put much of the land and industry in the hands of the state, which lacked effective methods of agricultural and industrial management. Confiscation of North American holdings triggered sanctions from the US, causing the country to lose its main trade partner and source of financial credit. Meanwhile, state expenditures increased dramatically due to investments in education, healthcare and other social programs. The military budget also soared in response to the Bay of Pigs invasion and the Missile Crisis. Adding to the economy's fragility, in 1963 Hurricane Flora caused huge devastation and losses. By that year, sugar and food production had declined drastically and the country's trade deficit grown alarmingly. Responding to this situation, in 1964 the government laid out a strategy for increasing sugar production over the next few years, with the goal of reaching ten million annual tons in the harvest of 1970. By rising sugar exports, the government expected to obtain the funds to invest in industrial growth, with the ultimate goals of lifting Cuba of underdevelopment and countering the US economic embargo (Mesa Lago 1981, 14-27, 16474; Guerra 2012, 172-81).

These conditions informed the theory of the New Man by contributing a redefinition of workforce and labor in dialogue with Marxist-Leninist ideology. The government adopted mass mobilizations and so-called voluntary work as instruments for pushing agricultural productivity up. A vast number of Cubans temporarily left their occupations to work in agriculture. Others labored in the fields during weekends and vacations, in addition to performing their regular jobs. Manual labor became a common denominator to all professions and acquired distinct political meaning as a measure of individual support for the Revolution. Government leaders equated work to a social duty. For Guevara, the New Man was a socially conscious, post-capitalist worker. Motivated by the personal desire to contribute to humanity, this Marxist-Leninist worker would be free from the mark of capitalist alienation: the material transaction of labor for money. In theory, political consciousness, instead of material incentives, acted as the engine of communist workers' productivity (Guevara 1966, 11, 15).

This mode of production presupposed an economy driven by political affects. The performance of daily heroism determined the New Man's structure of feeling. Williams's notion of structure of feeling as the affective elements of consciousness, the "particular quality of social experience [...] which gives the sense of a generation or of a period," is pertinent for interpreting the politicization of labor that Cubans lived through during these years (Williams 1977, 131). Political and economic discourse articulated that particular affective register through constant calls to perform exceptional deeds of dedication, discipline and sacrifice. In 1962, Fidel Castro met the multitudinous crowd celebrating Workers' Day in Revolution Square with a plead to work hard and make sacrifices: "We should make a great effort to improve our work [...] We should work better [...] We should harden the spirit, we should harden the hearts in this fight." Wrapped in anti-imperialist rhetoric, his message pronounced that the sacrifices of workers 
paved the way for the Revolution to prevail in the confrontation with the US: "Sacrifice is triumph, sacrifice is victory!" (Castro 1962, 61-62). On his part, Guevara exalted the New Man for facing everyday life with a heroic attitude: "The individual in our country knows that the glorious era in which he lives is one of sacrifice" (Guevara 1966, 21).

Of 54 new ballets that the BNC added to its repertoire from 1959 to 1970, a handful reflected on the country's social reality and illustrated facets of the New Man via direct representation or allegory. Enrique Martínez's El despertar (The Awakening, 1960), Victor Zaplin's Liberación (Liberation, 1963) and Azari Plisetski's La avanzada (The Outpost, 1963) depicted characters that fought political and military oppression; Alicia Alonso's La carta (The Alphabet Book, 1965) commemorated the teachers of the literacy campaign; and Alberto Alonso's Conjugación (Conjugation, 1970) memorialized Guevara two years after his death. ${ }^{17}$ None of these pieces, however, addressed the all too relevant topic of work. In regards to ballet, when considering the question of the transformation of the individual into a heroic worker one must shift attention from artistic production to the artists themselves. It was in social practice, by participating in agricultural activities, that ballet dancers corporealized the New Man doctrine of labor and its associated structure of feeling.

British dance critic Arnold Haskell, who visited Cuba twice during the 1960s, left his testimony of the BNC's participation in that decade's agricultural crusades. In one instance, on what was supposed to be their rest day, the dancers boarded a bus at 5:30 a.m. to travel to a farm in the outskirts of Havana. Upon arrival, "the artists [were] allotted a huge parcel of land in which to fill plastic bags with earth for planting of coffee." Under the burning sun, Alicia Alonso led through example, "demanding more and more barrow loads of earth" with a speed impressive to the critic. The dancers plodded on until completing their production goal (Haskell 1971, 21). Considering the physical demands of a profession in which long hours of training, rehearsals and performances must be followed by periods of necessary recovery, it was remarkable that dancers spent their rest day executing agricultural activities. In Haskell's description, they gave embodiment to the New Man's industriousness and morality of sacrifice, but, unfamiliar with a political discourse seeking to normalize heroism as everyday behavior, the foreign observer felt mystified by what in his own country would have been an unthinkable extension of ballet dancers' professional activities. ${ }^{18}$

Even ballet students took part in mass mobilizations to agriculture fields. In the wake of Hurricane Flora, in October 1963, Bohemia reported that a group of them had been among the thousands of men, women and children who spent a Sunday working in farmland recently nationalized in Havana Province. A photograph showed students under ten-years old sorting garlic seeds (Bernard 1963). Ballet students also participated in the escuela al campo or schoolto-the-countryside program adopted by the mid-1960s in middle schools and high schools across the island. Under this program, students lived and worked in farms for several weeks of the 
academic year. Jorge Esquivel, who trained between 1961 and 1967 before joining the BNC, recounted the variety of agricultural tasks that he and other students performed: "We harvested sugarcane and citrus fruits. We fumigated crops. We dug holes. We cut [the invasive bush] marabou" (Esquivel 2012).

The sugar campaign of 1970 marked the culmination of the social experiment to create the New Man. The calls for heroic work intensified as the country geared up for producing ten millions tons of sugar. Launching the historic harvest, Fidel Castro stressed that the desired yield could be achieved only through utmost workplace discipline, patriotism and "everyday heroism" (Castro 1969b, 62-63). A few weeks later, he compared the harvest to a military operation in which workers ought to display "the courage of constancy, the courage of tenacity, the courage of resilience." The politicization of physical labor came into sharp relief when he indicated that absolute dedication to work defined "the true concept of a revolutionary man" (Castro 1969a, 38).

Once again, ballet dancers exhibited their capacity for hard work and disposition to face the economy's challenges together with the rest of the nation. When the government asked the country's workforce to forego the Christmas' and New Year's holidays and join a massive twoweek operation to drive production up, the dancers of the Ballet de Camagüey, a troupe founded two years earlier in the city of that name, pledged to volunteer one hundred hours of labor each. Bohemia documented the artists' work in the plantation adjacent to the sugar mill Panama. On the final day, according to the magazine, the dancers were the last group to leave the field; they stayed at work longer than other groups with the goal of reaching the one-hundred-hour mark. Stressing the dancers' industriousness, the article explained that the troupe, without taking time for a break, went back to rehearsals immediately after its period of work in the harvest. The ensemble had less than two weeks to get ready for six performances of an ambitious program combining the second act of Swan Lake with four other ballets, including a world premiere (Pozo and Llanos 1970).

The six-page article contrasted photographs of the artists working in the fields and performing in the theater (Photo 3). In one group of images, they carried bunches of canes, undistinguishable from typical harvest workers. Another set of photos captured them in scenes from Swan Lake - the elegant ballerinas in resplendent white tutus. Significantly, a third category of images, depicting the dancers in class and rehearsal, unveiled the trait common to the sugar cane cutter and the glamorous swan: hard work in its most physically demanding form. The latter photographs allowed a glimpse into the labor of training and rehearsing: dancers mending slippers, exercising at the barre, practicing the choreography, drying their sweating bodies with towels and standing attentive while awaiting instructions. The text made the physical affinity between agricultural work and ballet explicit: "With their days in the harvest barely over, members of the ballet troupe already sweated copiously in rehearsals, which demand extraordinary physical resilience and strength" (4). The authors brought attention to both actual 
and symbolic correspondences between dancers and the ideal of the New Man. While the dancers' participation in the harvest constituted palpable instantiation of the Revolution's demand for heroic feats of labor, their displays of strength and resilience in rehearsals and performances allegorized the exhausting manual work expected from the New Man's proletarian body.
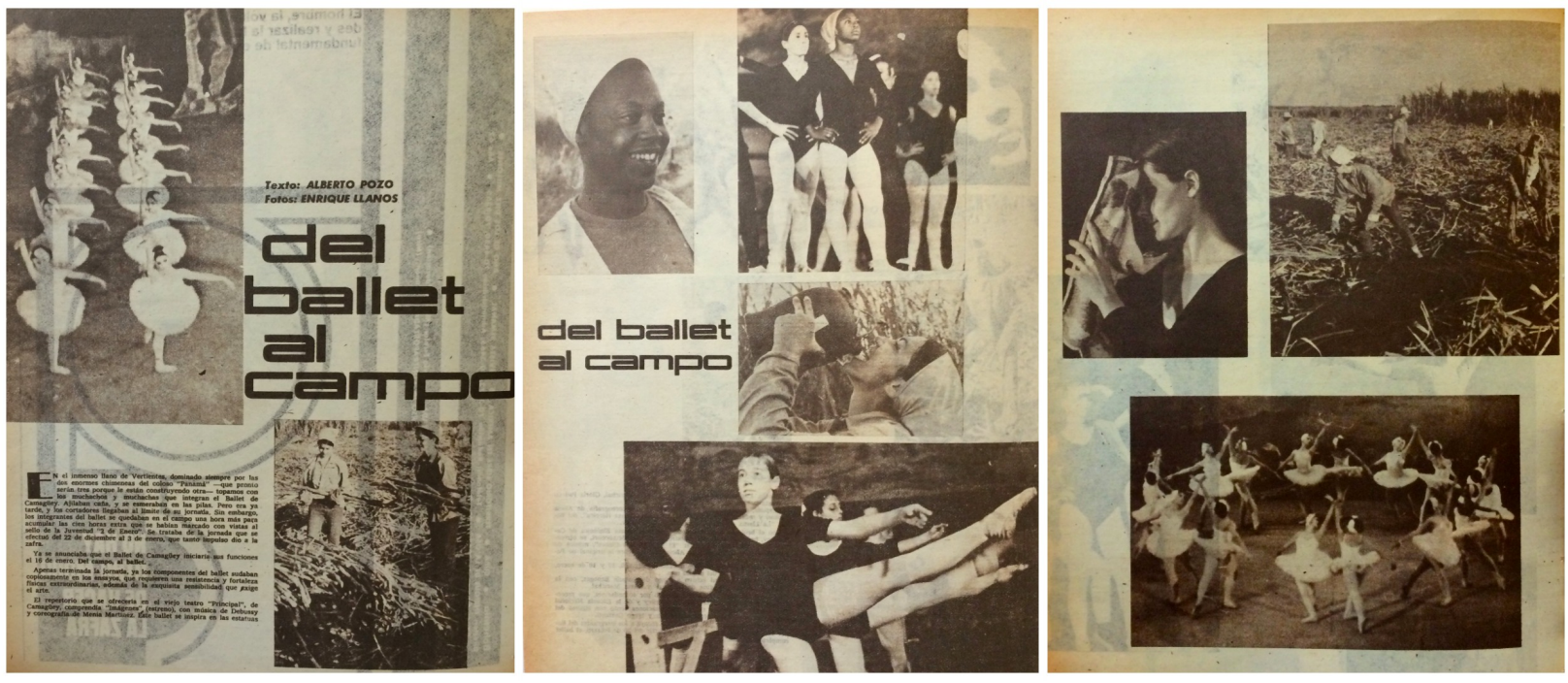

As the performances in popular venues and outreach visits to farms and factories, the dancers' participation in the harvest contributed to reconfiguring ballet's social identity in terms of both class and race. Historically associated with slavery, sugarcane cutting remained one of the most racialized forms of labor in Cuba. For centuries, this backbreaking activity had been performed by a predominantly Afro-Cuban workforce. In light of it, as Lillian Guerra notes, the media's contemporaneous depiction of educated, urban and white Cubans harvesting sugarcane encoded an official message of racial unity (Guerra 2012, 153). The photographs of the Ballet de Camagüey showed that at the time the troupe was composed of white artists, with the exception of one black ballerina. Even though the ensemble remained far from achieving racial integration, its deployment to the harvest conveyed the notion that, in a different way, the Revolution had eliminated a racial division of labor. The presence of the white artists in the fields suggested fluidity between the historically racialized identities of ballet dancers and sugarcane cutters. The article emphasized the notion of a deracialized division of labor by highlighting the troupe's sole black dancer in photographs that showed her in the distinct settings of the sugarcane field and the dance studio.

Every week over the length of the Ten-Million-Ton Sugar Campaign, Bohemia published accounts of the superhuman efforts of individuals immersed in the sugar production cycle. The article on the Ballet de Camagüey belonged within this type of press coverage, which sought to inform about the events of the campaign while publicly honoring the workers who excelled in it. More importantly, the reporting sought to energize the nation through the example of those 
workers. The intention of such journalism was to facilitate the pedagogical transformation of citizens into the New Man. For Guevara, the development of the New Man rested on the transmission of moral values from the political vanguard to the masses. Government leaders, members of the Communist Party and consummate workers would initially model the New Man for the rest of the population. Stimulated by those examples, individuals from the masses would strive to personify the New Man and, in turn, become themselves examples for others to follow (Guevara 1966, 12-13). Showcasing ballet dancers, Bohemia connoted that these artists stood within the political vanguard as models of the New Man's values for the rest of the nation.

The portrayal of the dancers' industriousness, then, was part of a discourse of propaganda. The media's exaltation of the ideal worker aided in constructing what Guerra defines as the hyper-reality of the Revolution: a grand narrative of utopianism maintained discursively and performatively, which, on the one hand, inspired social transformation and, on the other hand, obscured the shortcomings of the state's political project (Guerra 2012, 30). In comparison to the hyper-reality of model citizens who volunteered their labor and worked beyond exhaustion, lived reality comprised a wide range of individual responses to the authorities' demand for heroic labor. Many Cubans genuinely accepted the challenge of giving all their energy to the economy. Others, however, participated in the agricultural campaign under pressure, motivated not by political consciousness but by fear of official censure and retribution. The contradiction of so-called voluntary labor was its compulsoriness for those unwilling to perform it. ${ }^{19}$ As the Revolution developed authoritarian trends, the government expected Cubans to surrender their bodies to the state. The 1970 sugar campaign tested the government's control of those bodies (Guerra 2012, 240, 304). Under these circumstances, the participation of ballet dancers in the harvest was indistinguishable from a gesture of ideological obedience. It is impossible to know whether the dancers photographed by Bohemia authentically espoused the identity of the New Man or merely complied with an abhorred political obligation. Independently of the artists' private motivations, their public representation as laborious bodies symbolized the former, turning ballet dancers into ideological effigies of the hyper-real.

Testimonies of BNC dancers provide insight into how their agricultural work was valued, above all, as a performative intervention in the hyper-real construction of the New Man. Some accounts bring attention to the fact that traveling to farms and agrarian camps was a political gesture that did not necessarily translate into efficient labor and increased productivity. Unprepared for this type of work, artists could hinder rather than boost agricultural production. Ofelia González and Pablo Moré recalled an occasion when dancers were tasked with weeding coffee seedlings and, unable to differentiate the weeds from the seedlings, uprooted much of the coffee. In another instance, Moré, not knowing the correct angle for striking the sugarcane with a machete, cut through the cane and gashed his leg. According to González, situations like these could make the presence of dancers in the fields a burden for actual farmers. Moré recounted that over the years his enthusiasm for agricultural work waned. Initially, he had felt an authentic 
drive to contribute to the economy and in that way support the Revolution. With time, his ardor diminished: not only had he realized the inefficiency of the state's economic strategy, but also grown concerned about the risks of injury that agricultural work posed to a dancer's body (González and Moré 2015). Deeming their participation in agriculture a futile obligation, other dancers complied with it only in the most perfunctory manner. Once in the farms, they did little work. Caridad Martínez reminisced of a situation when she and a coworker spent their time in a banana farm creating a funny dance based on a popular beer commercial (Martínez 2013). Inefficiency and resistance were not unique to dancers. It characterized the actions of a large number of the workers mobilized to agriculture. Nevertheless, this work still carried value as a form of political theater in which the performance of manual labor, as publicized in the state media, signified national unity, identification with proletarian ideology and support of the Revolution (Guerra 2012, 317).

If ballet dancers symbolized the hardworking New Man so well, it was not only because, as noted thus far, they embraced a proletarian identity, participated in agricultural activities and evinced, in their own work, an arduous physicality akin to the rigorous manual labor done in farms and factories. As important as all this was the fact that, through its own work regime and institutional culture, ballet provided apt embodiment of the qualities of sacrifice, tenacity and discipline that informed the government's definition of labor. Ballet ethics exhibited an intrinsic alignment with the New Man's morality and structure of feeling. Here, Franko's (2002) argument that through choreography and performance dancers express the affective dimension of given political economies can be taken farther. The case of these ballet dancers and the Cuban Revolution shows that such correlation between dance, work and structures of feeling can also arise extra-choreographically, from the overlap between the institutional culture of a specific dance genre and the moral principles informing a particular economic model. A ballet troupe's routine of classes, rehearsals and performances, executed over long days and busy evenings and weekends, made dancers an example of dedication. They were workers who, as authorities expected, labored at all times. Undeterred by the exhaustion, pain and injuries common in their field, dancers also exemplified the courageous attitude that officials demanded from workers. At a time when the government called for increased productivity, ballet dancers' proverbial quest for technical improvement and artistic growth illustrated the perfectionist goal to give the best of oneself and maximize outcomes in the workplace. And having started training in childhood and persevered in pursuit of a profession they loved, dancers gave testimony, too, of the ardor that the Revolution expected workers to bring to their jobs. At the same time, the functioning of a ballet ensemble, in which classes, rehearsals and performances operate on the premises of individual discipline, responsibility and respect of authority, mirrored the norms of workplace behavior that the government attempted to implement. This perspective provides an additional way of looking at the relationship between ballet and communist ideology, which has been probed, as in the case of Ezrahi's (2012) examination of Soviet ballet, mainly in terms of the relationship between cultural policy and choreographic production. 


\section{Ballerinas for the Ten Million Tons of Sugar: The New Woman's Strength}

The urgency of integrating women in the workforce further supported the emergence of ballet as a compelling field for narratives of the New Man. The common view of ballet as a women's sphere rendered this art a generative space for symbolic representation of the relationship between women, work and ideology. For the most part, the article about the Ballet de Camagüey depicted women at work. ${ }^{20}$ In reaffirming a perspective of ballet as a female universe, it formulated the New Man's gender counterpart: an equally laborious New Woman. From the beginning of the decade, the Revolution had aimed to incorporate women into its political project and economic model. To this purpose, the Cuban Women's Federation, founded in 1960, actively promoted the philosophy that entering the workforce was a woman's right and duty: her means to achieve economic independence and social emancipation, and, at the same time, her obligation to the Revolution. Before 1959, only thirteen percent of working-age women had held a paid job; the remaining majority had worked in the domestic realm, honoring the patriarchal delimitation of female labor to household and maternal responsibilities. Under new circumstances that linked citizenship to productivity, this vast mass of housewives came to be seen as emblematic of the past and at odds with the Revolution. Absorbing them into the workforce became a political and economic necessity. In 1969, as the need to expand the labor force peaked in preparation for the Ten-Million-Ton Sugar Campaign, representatives of the Cuban Women's Federation knocked on the doors of 400,000 housewives. They asked them to support sugar production either through direct work in the fields and sugar mills or by filling jobs that men had left vacant in other industries after being deployed to the harvest. Over 144,000 female workers were recruited (Domínguez 1978, 500; Serra 2007, 118-19; Andaya 2014, 25 , 28-30).

In this context, the media exalted as much the figure of the New Man as that of the New Woman. If women were to perform agricultural and industrial jobs, it was necessary to alter long-standing perceptions of the type of work adequate for female bodies and the physical capabilities of those bodies. As hyper-real effigies of the New Woman, the ballerinas showcased in the article about the Ballet de Camagüey illustrated the desired redefinition of female labor. Not unlike the housewives asked to shift from domestic to public work, these dancers transgressed conventional female labor boundaries by moving from the feminized and "unproductive" sphere of ballet to the realm of agricultural work. Furthermore, a ballerina's body resolved key sociocultural contradictions that undercut the development of the New Woman. Since their incorporation into the economy did not abolish the social expectation that women performed maternity and household duties, female workers faced the daunting task of serving in physically exhausting jobs while remaining in charge of childrearing and other domestic responsibilities. (Andaya 2014, 31-36). Pushed to the limit, the productive female body should be capable of extreme vigor, endurance and determination-qualities that, as indicated already, ballet dancers perfectly exemplified. 
Not only did ballerinas give proof of those high levels of female strength and energy, but, also, they did so while upholding ideal femininity (Brill 2007, 217). Even while seeking to reshape the construction of womanhood through a redefinition of female labor, the media deployed a normative discourse of femininity in an institutional attempt to regulate the New Woman's physical appearance, as Serra contends. The possibility that agricultural and industrial work masculinized the female body had to be countered. Mujeres, the magazine of the Cuban Women's Federation, simultaneously praised the outstanding physical deeds of female workers and delivered advise on fashion and beauty, informing about the latest dressing trends in Paris and offering tips on waxing, tanning and applying makeup (Serra 2007, 242-43). The ballerina's body articulated the ultimate reconciliation of revolutionary toughness and conventional femininity, a point that Bohemia made eloquently by juxtaposing photographs of the same women carrying bunches of sugar cane and performing Swan Lake. ${ }^{21}$

An analysis of ballet dancers' personification of the New Man/Woman must take into account Alicia Alonso's identity qua poster artist of the Revolution. Deirdre Brill proposes that Alonso's work to develop ballet in her country, taken as a sign of personal dedication to a collective enterprise, reflected the New Man/Woman's commitment to fostering the greater social good (Brill 2007, 177-78). Moreover, as discussed earlier, the ballerina led a substantive effort toward the proletarianization of ballet through performances in popular venues and outreach events in workplaces. In parallel to this, a public narrative characterizing Alonso as a heroic worker crystallized over the course of the decade and, by 1970, lauded her as an undisputable example of the New Woman and an inspiration for a country embarked in the ambitious goal of producing ten million tons of sugar.

Already in the early 1960s, Bohemia associated Alonso's work ethics to the concept of the New Man/Woman. Several stories highlighted the colossal labor behind Alonso's performances, contextualizing it within the ideological discourse of the Revolution. The article "Alicia in the Land of Patriotic Socialism" (Maynulet 1961) explained that, after returning from a seven-month tour across the communist countries of Eastern Europe and Asia, Alonso and the BNC were not taking a moment of rest during rehearsals of new ballets. Engaged in "febrile activity," she and the other dancers were "giving their best" (53). Alonso posed for a photograph in black unitard and with a towel around her shoulder - the archetypical look of a ballet dancer in rehearsal. The underline dubbed her "the glory of Cuba," (52) signaling the correspondence between labor and nation building in official ideology. Bohemia reiterated this message in the article "Alicia Dances for the People" (González 1962), which advertised a performance by Alonso dedicated to the Committees for the Defense of the Revolution. ${ }^{22}$ A captioned photograph of the ballerina in rehearsal commented, "Alicia works daily, with rigor and discipline" (62). Another subtitled photograph of Alonso connected hard work to real artistry: "Daily work - constant, tenacious, rigorous - demands dedication. Thus do true artists emerge" 
(63). Turned into a leitmotif, the explanation of Alonso's work routine reappeared in an interview the following year. The ballerina insisted on her severe training regime: she took ballet class everyday, without missing one. Skipping a day, she maintained, was unthinkable. She was committed to "practicing, rehearsing, every day, every day of the year" (63). The dancer related an anecdote to illuminate this laborious daily practice:

Look, this is very funny and revelatory. Not long ago we were rehearsing here [...] A group of construction workers fixing the facility started to watch how we were dancing. After we finished the exhausting rehearsal, a mason told me, "Listen, do you realize that you sweat more [dancing] than us working?" In reality, ballet is hard and grueling, but, of course, I wouldn't trade it for anything else in the world! (A. Alonso quoted in García Suárez 1963, 29).

The anecdote suggested commonality and camaraderie between dancers and construction workers, implying the already familiar corollary that dancers were among the ranks of the proletariat. However, Alonso made a point of particular interest in suggesting that dancers sweated more, and thus exerted themselves harder than construction workers.

By the end of the decade Alonso was recognized as a national paradigm of the New Man/Woman. Between August 1969 and June 1970, over the span of the Ten-Million-Ton Sugar Campaign, Bohemia published no less than five articles on the ballerina. Their underlying narrative highlighted Alonso's political persona, casting the arc of her career in patriotic terms. Throughout the 1940s and 50s, she had enjoyed international recognition as one of the best ballerinas of her generation, a star of Ballet Theatre and the Ballets Russes de Montecarlo in the United States. In Cuba, she used her prominence as a public figure to denounce Batista's dictatorship. When Fidel Castro arrived to power in 1959, she enthusiastically embraced the ethos of the Revolution, but tensions between the US and Cuba put her in the disjunctive of choosing between New York and Havana - according to her, after 1960 the US would extend her an entry visa only if she agreed to defect. In this situation, Alonso opted to give up her star contracts in North America and work toward developing and popularizing ballet in her country. She joined the Communist Party and lent her face to political organizations such as the Cuban Women's Federation and the Committees for the Defense of the Revolution. Furthermore, she served as a magnificent cultural ambassador of the Revolution in tours to the Soviet Union, China, Latin America and countries in both Eastern and Western Europe (Díaz Castro 1969, 1970; Cabrera 1970).

As important as the construction of Alonso's political profile was the inscription of certain points of her biography within the narrative of heroism igniting the sugar campaign. In general, biographies of great prima ballerinas retell the story of the devoted artist who overcomes limitations, disregards setbacks, asserts herself in a highly competitive field and ultimately 
achieves success - only to realize that, having arrived to the apex of the ballet world, she must work as hard as ever, if not harder, to maintain her position and fight physical decline. For Alonso this narrative could have not been any more dramatic: she overcame serious visions problems that normally would have put an end to a ballet career. Some of the articles alluded to this unusual situation and highlighted the impressive display of grit that led to Alonso's serendipitous debut in the title role of Giselle in New York, in 1943- the turning point in her rise to prima ballerina. Two years earlier, while performing with Ballet Theatre, she had hit a set backstage and experienced a retina detachment in one of her eyes. After surgery, the doctors prescribed her strict rest. Even is she had to lie in bed with the head immobilized, Alonso continued to exercise the legs. Two other surgical interventions were necessary after it was determined that the retina had detached also in the other eye. Her confinement to bed extended for a year and half, but Alonso did not stop working. She rehearsed ballets in her mind and marked the steps with her fingers. After the long rest period, Alonso had to relearn walking. As soon as she could, she went back to the studio to regain her dance skills through patient work. Against all odds, she rejoined Ballet Theater and, two months later, was presented with the opportunity to replace a suddenly ill Alicia Markova in Giselle. With five days to prepare, she had to rehearse a role she had never danced before while continuing her pre-scheduled appearances in other programs of Ballet Theatre's season. Alonso recalled, "This meant spending 16 to 18 hours [a day] without removing my ballet shoes. By the evening of the performance, my heels had turned into two enormous blisters that made me suffer atrociously." (A. Alonso quoted in Pacope 1969, 95). Her point shoes were soaked in blood by the end of the performance.

Even if this chapter of Alonso's career predated the Revolution, Bohemia appropriated the story in its discursive production of the New Man/Woman's epic identity. Alonso's inspirational tale exhibited degrees of passion, devotion and heroism that conjured the sugar campaign's structure of feeling. A journalist described Alonso's route to fame as one of "much effort, many sacrifices and many years of hard and ceaseless work" (95). Another journalist affirmed, "Alicia is passion [and dances with] that indefatigable heart of hers, which has made her triumph over the traps that life has set on the path of her career." For this writer, the ballerina's artistic greatness stemmed not from genius, but from her all too evident "will of titanium" (Quiroga 1970, 35). Going beyond allegorical associations of Alonso's temperament to the New Man/Woman's morality, two other articles explicitly linked the ballerina to the unfolding historical event of the sugar campaign. Their titles connected Alonso to 1970, officially named the "Year of the Ten Millions" by the government and recognizable as such by readers. The article "Alicia of 1970" (Photo 4) announced that, "in the midst of the sugarcane harvest of 1970", the Cuban audience would be regaled with the opportunity to see the inspirational artists in performances with the BNC (Díaz Castro 1970, 4). Meanwhile, the essay “The Fabled Alicia Alonso in 1970" (Cabrera 1970) exhorted readers to pay tribute to Alonso as a model to emulate in the national effort of the harvest: 
As we face 1970, a year in which all our nation fights the decisive combat against the claws of economic and mental underdevelopment, we cannot but bow respectfully to the work of a figure of exceptionality who has known how to keep alive, in the past and in the present, the faith in the talent of our people, and how to show us the high summits that we are capable of climbing. (95)

Without question, a ballet dancer had come to symbolize the mythical revolutionary, the human engine of political and economic transformation, the New Man/Woman envisioned by the ideologues of the Revolution.

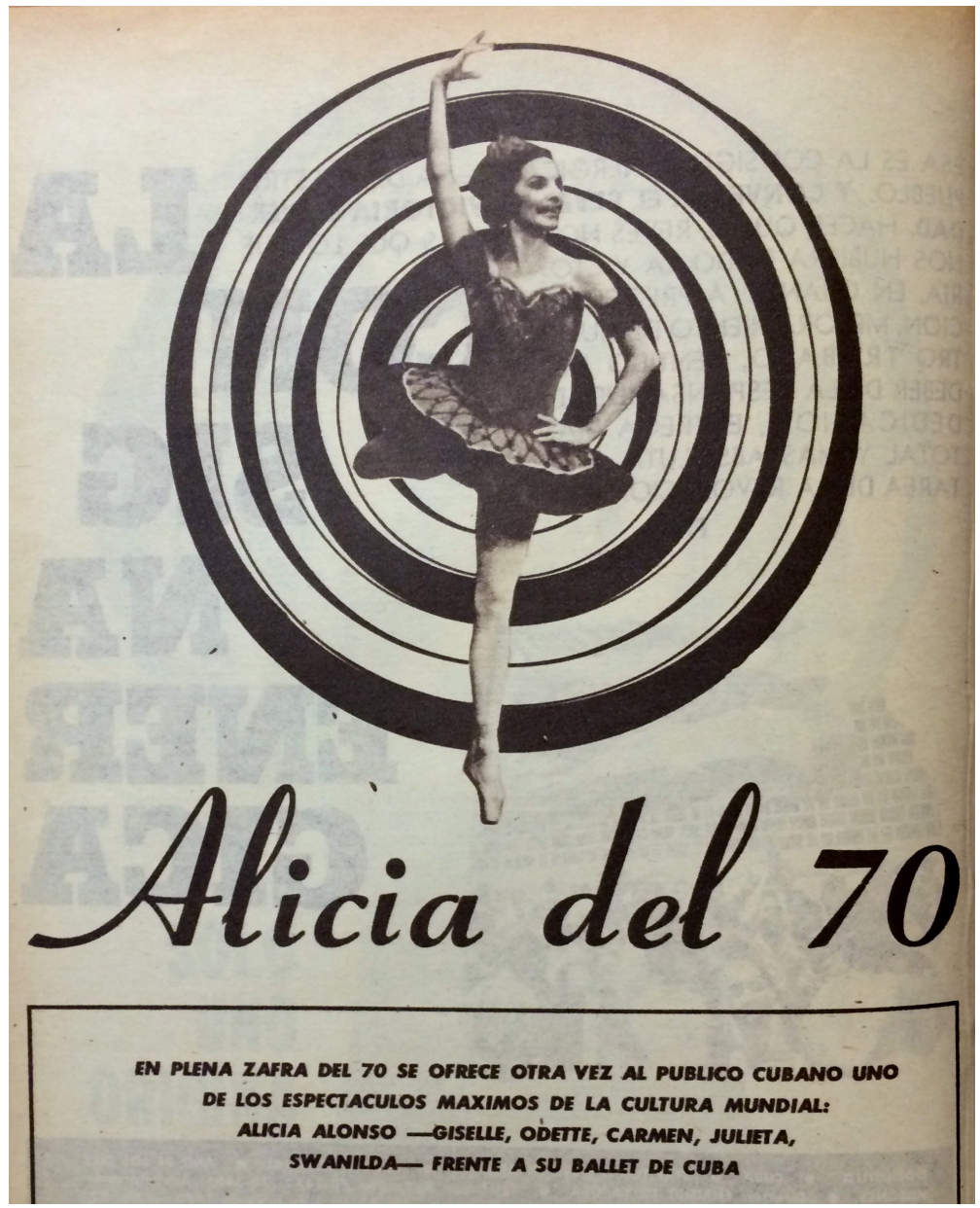

On May 19, 1970, Fidel Castro announced to the nation that the crusade to produce ten million tons of sugar had failed. According to Castro, though scores of Cuban workers had made a display of "superhuman effort," the harvest had suffered from "inefficiencies," "weaknesses" and "limitations" (Castro 1970). Although authorities would not acknowledge it, those inefficiencies, weaknesses and limitations constituted a clear mark of distinction between the reality of only too human citizens and the hyper-reality of the New Man/Woman. As Guerra 
contends, by the late 1960s the unfolding events of the Revolution collapsed the real and the hyper-real, but, under circumstances in which the production of ideology relied so heavily on myth-making, the grand narrative of the Revolution often superseded experience (Guerra 2012, $317-18,325-26,330)$. The failure to meet the harvest's goal called into question an affect-driven economic model based on the capacity of the ideal revolutionary to work beyond exhaustion, motivated by political consciousness and paying a high price in personal sacrifices. The expectation that a whole nation adopted this heroic behavior and lifted itself from underdevelopment through sheer physical exertion had been quixotic. The majority of the men and women who tried to rise to this challenge found its bodily and moral demands unrealizable. Attempts to personify the New Man/Woman were what Guerra identifies as performances of political beliefs, approximations to an unachievable ideal that bridged the gap between the real and the hyper-real only momentarily and imperfectly (Guerra 2012, 317, 351).

Ballet dancers, as argued here, immersed themselves fully in the complex ideological operations of this period. In both praxis and discourse, they were dynamic participants in the construction of the New Man/Woman. Their work in agriculture attested to the real attempts of the Revolution's supporters to live up to the ideal of a communist worker who selflessly lent his time, stamina and emotions to the Revolution. In committing their bodies and affects to an economy of heroism, dancers emerged as eloquent examples of the corporeal and moral transformation of the revolutionary subject. Their convincing performances of the New Man/Woman, which resonated with ballet's own superlatives claims on the bodies, feelings and ethics of its practitioners, endowed these artists with an active role in the production of ideological discourse. Having positioned themselves as persuasive illustrations of an idealized labor paradigm, they intervened in the reproduction of the New Man/Woman's myth and the writing of a hyper-real narrative of the Revolution. Even if the Ten-Million-Ton Sugar Campaign failed, for the Cuban ballet the harvest was ultimately a success: a critical juncture for consolidating the image of the ballet dancer as a worker of the Revolution. The harvest marked the culmination of the decade-long process of proletarianizing ballet. The quest to align the practice of ballet with the cultural policies of the Revolution might have placed great emphasis on popularizing the art form among the masses, but redefining the social identity of ballet dancers was an equally crucial imperative in a society modeled upon Marxist principles and invested in the radical transformation of the individual. While there is ample evidence of the politicization of ballet in communist regimes, the case of Cuba reveals the original possibilities for espousing official ideology that dancers found in the communist concept of labor and its expression in ballet. Engaging with this economic category, dancers signified a production mode and articulated class affiliation in ways indicative of their political participation in the Revolution.

Over the next decade, Cuban ballet dancers would continue to serve as models of industriousness. Despite the fact that the Ten-Million-Ton Sugar Campaign exposed the 
limitations of economic theories centered on the ideal of the New Man/Woman, the aftermath of the harvest saw the government renew its calls for increased commitment to productivity. With the imperfections of the nation's workforce laying bare, now authorities harangued Cubans not so much into becoming superhuman workers as into not succumbing to idleness, absenteeism and inefficiency. Ballet dancers' hard work endured as a valuable metaphor within this renewed official discourse, while dancers continued to enjoy official recognition for their productiveness. In 1973, the Cuban Workers Confederation would confer its Labor Day Distinction upon Alicia Alonso. Three years later, the same organization would bestow upon her the highest honor to which a Cuban worker could aspire: the title of National Labor Hero (A. Alonso 2004). ${ }^{23}$ No award could have expressed better, through its name, the symbolism of a ballet dancer's work for the Revolution.

\section{Works Cited}

Alonso, Alicia. 2004. Diálogos con la danza, fourth edition. México City: Oceáno.

Alonso, Fernando. 1953. "Ponencia presentada en el Congreso Continental de Cultura." In Raúl Ruiz, Fernando Alonso: danza con la vida. Havana: Letras Cubanas, 2000: 142-47.

Andaya, Elise. 2014. Conceiving Cuba: Reproduction, Women and the State in the Post-Soviet Era. New Brunswick: Rutgers University Press.

Ballet Alicia Alonso. 1951. "Propósitos que dieron origen y dan vida al Ballet Alicia Alonso" (mission statement). Reproduced in Miguel Cabrera, Órbita del Ballet Nacional de Cuba. Havana: Orbe, 1978: 122-23.

Ballet de Cuba, 1959a. Giselle. Souvenir program, September 17, Auditorium Theatre, Havana. Museo Nacional de la Danza, Havana.

. 1959b. Las silfides, Cuatro fugas, El cisne negro. Souvenir program, February 3, Blanquita Theatre, Havana. Museo Nacional de la Danza, Havana.

Bernard, Jorge L. 1963. "Un domingo de trabajo voluntario." Bohemia (Havana), October 25. Bosch, Aurora. 2014. Interview with the author. London, June 28.

Brill, Deirdre. 2007. "La Escuela Cubana: Dance Education and Performance in Revolutionary Cuba." PhD dissertation. University of Pennsylvania.

Cabrera, Miguel. 1970. "La fabulosa Alicia Alonso en 1970." Bohemia, February 6: 94-95. . 1998. Ballet Nacional de Cuba, medio siglo de gloria. Havana: Ediciones Cuba en el Ballet.

. 2014. Interview with the author. Havana, January 15.

Castro, Fidel. 1961. "Palabras a los intelectuales." Transcript of speech at the National Library, Havana, June 30, 1961. Bohemia (Havana), July 30: 44-51.

- 1962. "Sacrificio es triunfo, sacrificio es victoria sobre el imperialismo." Transcript of speech at Revolution Square, Havana, May 1, 1962. Bohemia (Havana), May 4: 56-63. - 1969a. "Como en una guerra, se han movilizado nuestras Fuerzas Armadas Revolucionarias para la zafra de los diez millones." Transcript of speech at the Ministry 
of the Revolutionary Armed Forces, Havana, November 4, 1969. Bohemia (Havana), November 14: 34-39.

- 1969b. "No se trata de conquistar en 1970 los diez millones, sino de mantenerlos." Transcript of speech at the Chaplin Theater, Havana, October 27, 1969. Bohemia (Havana), October 31: 58-69.

. 1970. Transcript of speech at the public esplanade across former US Embassy, Havana, May 19, http://www.cuba.cu/gobierno/discursos/1970/esp/f190570e.html. Accessed on July 14, 2016.

Chen, Yinghong. 2009. Creating the "New Man": From Enlightenment Ideals to Socialist Realities. Honolulu: University of Hawaii Press.

Daniel, Yvonne. 1995. Rumba: Dance and Social Change in Contemporary Cuba. Bloomington: Indiana University Press.

de la Fuente, Alejandro. 2001. A Nation for All: Race, Inequality, and Politics in TwentiethCentury Cuba. Chapel Hill: University of North Carolina Press.

Díaz Castro, Tania. 1969. "Con Alicia de doce a una.” Bohemia (Havana), September 12: 26-27. . 1970. "Alicia del 70." Bohemia (Havana), June 5: 4-9.

Domínguez, Jorge. 1978. Cuba: Order and Revolution. Cambridge: Harvard University Press.

Esquivel, Jorge. 2012. Interview with the author. San Francisco, May 25.

"Experiment in Music Appreciation: Distinguished Cuban Musicians Advice Programme." 1966. Granma (Havana), English edition, March 6: 6.

Ezrahi, Christina. 2012. Swans of the Kremlin: Ballet and Power in Soviet Russia. Pittsburgh: University of Pittsburgh Press.

Franko, Mark. 2002. The Work of Dance: Labor, Movement and Identity in the 1930s. Middletown: Wesleyan University Press.

García Suárez, Pedro. 1963. "The first steps of Alicia Alonso.” Bohemia (Havana), February 15: 28-30.

González, José R. 1962. “Alicia baila para el pueblo.” Bohemia (Havana), June 22: 62-63.

González, Ofelia, and Pablo Moré. 2015. Interview with the author. Rome, June 11-12.

Gordon-Nesbitt, Rebecca. 2015. To Defend the Revolution is to Defend Culture: The Cultural Policy of the Cuban Revolution. Oakland: PM Press.

Guerra, Lillian. 2012. Visions of Power in Cuba: Revolution, Redemption and Resistance, 19591971. Chapel Hill: University of North Carolina Press.

Guevara, Ernesto. 1966. El socialismo y el hombre [en Cuba]. Montevideo: Nativa Libros. Haskell, Arnold. 1971. "An Appreciation of the Artist and the Human Being." In Tana de Gamez, Alicia Alonso at Home and Abroad. New York: Citadel Press: 15-21.

John, Suki. 2012. Contemporary Dance in Cuba: Técnica Cubana as Revolutionary Movement. Jefferson: McFarland.

Kapcia, Antoni. 2005. 'Educational Revolution and Revolutionary Morality: The 'New Man,' Youth and the new 'Battle of Ideas'.” Journal of Moral Education vol. 34, (4): 399-412. 
Law no. 812. 1960. Republic of Cuba. Reproduced in Miguel Cabrera, Órbita del Ballet

Nacional de Cuba. Havana: Orbe, 1978: 138-141.

"Manifiesto de los Intelectuales y Artistas Cubanos." 1961. Bohemia (Havana), June 11: 44.

Martí, José. 1891. “Odio la máscara y vicio.” In Versos sencillos. New York: Louis Weiss: 1618.

Martín, Randy. 1994. Socialist Ensembles: Theater and State in Cuban and Nicaragua.

Minneapolis: University of Minnesota Press.

Martínez, Caridad. 2013. Interview with the author. New York City, August 24.

Maynulet, Gustavo. 1961. "Alicia en el país del socialismo patrio.” Bohemia (Havana),

September 24: 52-53.

Medialdea, Ernesto. 1962. "La TV y la radio nacional en Oriente.” Bohemia (Havana), August 3:

70-72.

Mesa Lago, Carmelo. 1981. The Economy of Socialist Cuba: a Two-Decade Appraisal.

Albuquerque: University of New Mexico Press

"Mujer cubana, sitúate en primera fila." 1962. Bohemia (Havana), October 5: 48-49.

Navarra, Noel. 1964. "Un arte exquisito al alcance de todos." Bohemia (Havana), July 24: 46-51.

Núñez, Carlos. 1962. "Ballet para el pueblo.” Bohemia (Havana), June 29: 43.

Pacope. 1969. "Orto de una estrella: la primera vez que bailé 'Giselle'”. Bohemia (Havana),

August 1: 94-95.

Pozo, Alberto and Enrique Llanos. 1970. "Del ballet al campo.” Bohemia (Havana), February 27:

4-9.

Quiroga, Orlando. 1962a. "De viernes a viernes.” Bohemia (Havana), May 11: 76-77.

. 1962b. "De viernes a viernes." Bohemia (Havana), June 29: 41.

- 1962c. "De viernes a viernes." Bohemia (Havana), August 3: 72.

- 1970. “Alicia en el país de la ciencia-ficción.” Bohemia (Havana), April 3: 34-35.

Robertson, Michael. 1979. “A Cuban Ballet Star Who Cuts Sugar Cane.” New York Times, July

15: D18.

Ross, Janice. 2015. Like a Bomb Going Off: Leonid Yakobson and Ballet as Resistance in Soviet Russia. New Haven: Yale University Press.

Serra, Ana. 2007. The "New Man" in Cuba: Culture and Identity in the Revolution. Gainesville: University Press of Florida.

Williams, Raymond. 1977. Marxism and Literature. Oxford: Oxford University Press.

\section{Notes}

I express my gratitude to the BNC figures who generously shared their memories in the interviews cited here: Aurora Bosch, Miguel Cabrera, Jorge Esquivel, Ofelia González, Caridad Martínez and Pablo Moré. While relying on their valuable testimonies, the views expressed in this article are mine and do not necessarily coincide with the interviewees' opinions. I am also grateful to Pedro Simón and Ahmed Piñeiro, from the National Dance Museum, in Havana, and the staff of the Cuban Heritage Collection, at the University of Miami, for facilitating access to photographs and other archival materials. I appreciate a 
conversation with Yvonne Daniel about the parallel between ballet ethics and the Revolution's ethic, which spurred this research. I also appreciate the beneficial input of the anonymous reviewers, as well as the stimulating panel discussions with Eugenia Cadús, Victoria Fortuna, Ramón Rivera-Servera, Ana Serra and Carlos Uxo in conferences of the Latin American Studies Association and the Society of Dance History Scholars in which I presented earlier versions of this work. I thank Justin Crumbaugh and Helen Thomas for their editorial suggestions. I also extend my appreciation to institutions that sponsored this scholarship through research grants: the National Endowment for the Humanities, Smith College and Harvard University's David Rockefeller Center for Latin American Studies.

${ }^{1}$ Translations from Spanish into English are mine unless otherwise indicated. Guevara's classic essay first appeared as a letter to the editor in the Uruguayan weekly Marcha on March 12, 1965. Here, citations are of a reprint titled El socialismo y el hombre (Montevideo: Nativa Libros, 1966). In subsequent editions, the text came to be known by its definitive title: El socialismo y el hombre en Cuba.

${ }^{2}$ Throughout the article, I refer to the "1960s" not in a strict chronometric sense, but adopting a periodization of the initial "decade" of the Revolution that includes the bookend years of 1959, when the Revolution arrived to power, and 1970, when its leaders attempted the landmark Ten-Million-Ton Sugar Harvest.

${ }^{3}$ Historians of the Revolution have examined the symbiotic relationships between education, labor and the arts in formulations of the New Man - both in the ideological discourse that defined this model of homo politicus and in concrete performances of the ideal revolutionary, incarnated more or less perfectly by scores of Cubans who participated in the Revolution's project (Kapcia 2005, Serra 2007, Chen 2009, Guerra 2012). In a dissertation on the politicization of dance under the Revolution, Deirdre Brill pays attention to responses within dance to the ideology of the New Man not in the 1960s, as I do here, but in the 1970s. Brill considers the development of amateur dance groups and training of dance instructors, as well as choreographic representations of sexuality, race and ideology in ballet, modern dance and folkloric dance ensembles. She takes note of dancers' participation in agricultural work and outreach initiatives to popularize ballet, points that I seek to develop further here (Brill 2007, 153-54, 166-67). Yvonne Daniel's Rumba: Dance and Social Change in Contemporary Cuba (1995) and Suki John's Contemporary Dance in Cuba: Técnica Cubana as Revolutionary Movement (2012) provide additional insight into the Revolution's politicization of dance.

${ }^{4}$ Edited weekly, abundantly illustrated and covering a broad range of political and cultural events, state-controlled Bohemia provides comprehensive documentation of Cuban history-including ballet history-from an official perspective. For decades, the magazine has been among the Cuban publications with the most influence and largest circulation.

${ }^{5}$ Castro's "Words to the Intellectuals" enounced the official definition of freedom of artistic expression. The speech assured artists of freedom to work within any aesthetic while qualifying that content politically contrary to the Revolution would not be tolerated. Rebecca Gordon-Nesbitt provides a detailed analysis of the politics of stylistic freedom in the Cuban arts during the 1960s (Gordon-Nesbitt 2015, 124-32, 195-203).

${ }^{6}$ Frederick Taylor (1856-1915) was among the pioneers of scientific labor management. The theories collectively known as Taylorism sought to increase productivity through the rationalization and standardization of workers' movements - with the goal of minimizing the execution time and effort of iterative actions. 
${ }^{7}$ In Spanish, Conjunto de Danza Moderna, Instituto Cubano del Arte e Industria Cinematográficos and Imprenta Nacional.

${ }^{8}$ The event (Congreso Continental de Cultura, in Spanish) took place in April 1953. Fernando Alonso did not attend, but his speech was read to the audience by Cuban poet Nicolás Guillén. It declared, "ballet, born in the courts of Italy and France, art of the elites, palatial art par excellence, is starting to grow roots among the people [and] support the common man, the man of the working class, in his intellectual and artistic development" (F. Alonso 1953, 144). In line with this statement, the Alonsos' troupe undertook a number of initiatives to popularize ballet in Cuba. For instance, on January 8, 1949, it performed for free for thousands of spectators at the stadium of the University of Havana - an unprecedented event in the country. Also, in addition to dancing in traditional ballet venues such as Havana's Auditorium Theater, throughout the 1950s Alicia Alonso performed in the Nacional, Fausto and America movie-theatres before audiences that otherwise would have not encountered ballet. This was a period in which, according to Cuban ballet historian Miguel Cabrera, the company helped to popularize the dance form by offering a number of presentations for free, or at affordable prices, in public venues in Havana and other locations (Cabrera 1998, 16-17). In-text citations of Alicia and Fernando Alonso include their first names' initials for differentiation.

${ }^{9}$ These words referenced a famous stanza in which José Martí (1853-95), the Cuban poet and national hero, expressed his desire to live among peasants in the country's mountains - the "poor of the land" (Martí 1891).

${ }^{10}$ In Spanish, Federación de Mujeres Cubanas.

${ }^{11}$ In Spanish, Consejo Nacional de Cultura and Central de Trabajadores de Cuba.

${ }^{12}$ Cabrera generously shared records of the hundreds of outreach events that he organized for the BNC from 1970 until 2013. Equivalent records from the 1960s have not been preserved in the archive of the BNC historian.

${ }^{13}$ Quoted in English by Gordon-Nesbitt.

${ }^{14}$ Similar outreach initiatives promoted other artistic expressions among the working classes. In 1968, a group of actors from Havana founded Teatro Escambray with the express purpose of performing in the Escambray mountain range. The ensemble followed an anthropological approach to theatrical production. The artists lived with peasants, collected their testimonials and created plays for rural audiences that reflected the complex transformations that the Revolution had brought to the lives of farmers (Martin 1994, 130).

${ }^{15}$ According to Cabrera, this was a favorite anecdote of Alonso.

${ }^{16}$ Unprecedented admission of black students in ballet schools, as indicated here, constituted another response of the Cuban ballet to the Revolution's program to end racial discrimination. The article "An Exquisite Art Within Everybody's Reach," published in Bohemia in 1964, highlighted the new opportunities for Afro-Cubans to study in the Provincial Ballet School of Santiago de Cuba (Navarra 1964). In parallel to this, throughout that decade the BNC produced works that incorporated Afro-Cuban themes, music and dance, such as Lorenzo Monreal's Mestiza (1966), Pedro Díaz Reyes's Ochosí y el venado blanco (1967), and Alberto Alonso's El güije (1967) and La rumba (1968). In spite of gains in racial integration in the 1960s and 1970s, the 1980s would see the emergence of controversy about proportional representation and advancement opportunities for Afro-Cuban dancers, especially female black dancers, in the BNC (Martínez 2013). While in urgent need of scholarly examination, such 
controversy cannot be rightfully addressed within the scope and timeframe of this article. In a book manuscript under preparation, I provide more extensive analysis of the racial politics of the Cuban ballet.

${ }^{17}$ During this period, the artistic production of the Revolution generated multiple representations of the New Man. Analyzing that decade's novels, Serra confirms the recurrence of characters who tackle the challenge of becoming the New Man - either succeeding or failing at it (Serra 2007).

${ }^{18}$ Cuban ballet dancers' personification of the hardworking New Man would also cause perplexity among North American critics when the troupe visited the US the following decade. In 1979, a profile of Jorge Esquivel, the BNC's lead male dancer, appeared in the New York Times under the title "A Cuban Ballet Star Who Cuts Sugar Cane.” It drove attention to the paradox of dancers performing agricultural work. In his declarations, Esquivel drew a picture of politically conscious dancers who engaged actively in the various tasks of supporting the Revolution while transcending the role of artists under a traditional division of labor: "When there's work to be done in the fields, we help pick crops. It's on a voluntary basis, but I'm glad to do it [...] I got these calluses from cutting sugar cane. People outside Cuba have asked me, 'How can you cut cane? You're an artist!' But I'm happy to do it; I'm not better than the next guy [...] I feel I'm helping Cuba whether I'm dancing well on stage or cutting cane in the fields [...] The Revolution taught us to be equal. We don't have different classes in Cuba" (Robertson 1979).

${ }^{19}$ Guerra documents the cases of members of a theater group who complained that "voluntary work" was a euphemism for a requirement, high school students who were nominated to perform such work in meetings in which they were not present and other students who self-inflicted wounds to avoid working in the harvest (Guerra 2012, 275, 328, 311).

${ }^{20}$ The article's photographs of the harvest showed 14 women and five men; those of performances, 41 women and six men; and those of rehearsals, 23 women and no men. This tally does not take into account a few figures whose gender is not recognizable because of the grainy resolution of images.

${ }^{21}$ The notion of a productive female body pushed to the maximum of its labor capacity found another clear manifestation in the sphere of ballet pedagogy, which implications for the development of the Cuban ballet. With the inception of state-supported ballet schools in 1961, the number of ballet students expanded dramatically and women had to meet the sudden demand for teachers. Young ballerinas of the BNC were called upon to fulfill teaching responsibilities in the National and Provincial Schools of Ballet, in Havana. The ballerinas were among the troupe's leading soloists: Loipa Araújo, Aurora Bosch, Ramona de Sáa, Josefina Méndez and Mirta Plá. Except de Sáa, whose stage appearances had been compromised by an injury, the other artists were at a moment of ascent in their performing careers. They found themselves in the unusually demanding circumstances of working fulltime as BNC dancers while teaching many of the classes in the schools. As Bosch recalls, technique courses in the schools had to be scheduled for 7:00 a.m. so that she and the other teachers were free by mid-morning, in time to join the $\mathrm{BNC}$ for a full day of classes, rehearsals and, on many days, evening performances (Bosch 2014). These ballerinas, who followed Alicia Alonso in the artistic hierarchy of the troupe, had major obligations as performers. Consubstantially to the New Man/Woman ideology and its requirement of heroic effort toward the construction of a new society, the state system of ballet schools presumed its teachers' exertion and commitment to the task of securing the future of the Cuban ballet.

${ }^{22}$ Comités de Defensa de la Revolución, in Spanish. 
${ }^{23}$ A list of Alicia Alonso's distinctions appears in the companion multimedia DVD of her book Diálogos con la danza (2004). 